\title{
The Contribution of Self-Concept to assist Career Planning of Student
}

\author{
Gita Yandri Yetni ${ }^{1}$, Mudjiran ${ }^{2}$, \& Alwen Bentri ${ }^{3}$ \\ ${ }^{123}$ Universitas Negeri Padang \\ *Corresponding author, e-mail: Gitayandri1@gmail.com
}

\begin{abstract}
This study aims to describe the contribution of self-concept to career planning. The study is to be descriptive with population class XI and XII in SMAN 1 V Koto Timur which totaled 272 students with samples of the study amounted to 162 students. The technique used in sampling uses stratified random sampling. The research instrument uses a Likert measurement scale model. The data obtained were analyzed using percentage techniques. The research findings show that self-concept: (1) the perceptual or physical self-concept are a picture of a person associated with physical appearance being in the category of high; (2) conceptual or psychological self-concept which is also called psychological self-concept is a picture of a person of himself, his abilities or disabilities, his future, and includes the quality of his life change, honesty, self-confidence, freedom, and courage on the category of high; (3) attitudinal is a component that involves how individuals weigh their feelings about themselves about individual attitudes now and also hopes are in the high category. Students still lack self-understanding related to their future. Ideally, students who have careful planning for their careers have positive self-concepts. The successes and failures of students in determining their career planning are closely related to students 'selfunderstanding, students' understanding of the environment and career information obtained from career guidance in their schools.
\end{abstract}

Keywords: self-concept towards career planning.

This is an open access article distributed under the Creative Commons 4.0 Attribution License, which permits unrestricted use,

distribution, and reproduction in any medium, provided the original work is properly cited. $\odot 2020$ by Author

\section{Introduction}

Career planning refers to how much the individual has done thinking about and planning various educational and employment opportunities. Career planning is a picture of a person's activities based on self-understanding and understanding of the environment to enter a life order in a particular society that is always changing its development. In line with the opinion on the above (Nengsih et al., 2015) said Planning for a career is one of the important aspects in the stage of one's career development, it will help a person design a future framework. Planning a career done as early as so that the framework is sturdy and strong to support a successful future. In line with the opinion (Sharf, 1992) that "Career 
planning refers to how much thinking and planning they have done about various educational and occupational opportunities". The statement explains that the world of work is very complex because it involves the source of life of many people and is needed especially at the age of productive work.

Decisions about the choice of occupation, position or career that aspired person has a close connection with the education pursued and had we completed. Opinions on the top line with (Fadli et al., 2017) said Education is part of a person's career in the early journey of preparing for certain types of work. I believe the suitability of work with the state of self to bring them to live it well. The decision of high school students specifically about the education chosen has direct implications for employment, positions/careers aspired after completing studies at the level of education being pursued. (Annisa Apriliyanti, Mudjiran, 2016) revealed that the results of the actions will encourage someone to do a self-assessment, self-assessment is a concept of a person. The self-concept is the opinion or assessment of adolescents about themselves. Stating that the concept of self is a belief and assessment of someone about himself. It relates these beliefs to talents, interests, abilities, physical and psychological assessments. "The concept of self (self-concept) as an opinion or feeling, and someone's description of himself whether it concerns material, physical, (body), and psychological (social, emotional, moral, and cognitive) that a person has". Adolescents have positive and negative self-concepts towards themselves. Adolescents who see themselves as lacking a clear self-concept will emerge negative self-concept towards adolescents such as adolescents who feel inferior, do not have definite goals, are pessimistic in facing the future.

Based on interview premises, counselor school SMAN $1 \mathrm{~V}$ Koto Timur students do not understand what is in want themselves, less confident with options and capabilities. Students are more influenced by the opinions of others about themselves. A student should match their career choices with their personalities. The phenomenon that occurs in SMAN 1 $\mathrm{V}$ Koto Timur students in choosing tertiary education majors is more likely to expect help from subject teachers, counselling and guidance teachers, parents and go along with their friends' choices. They expect an opinion from the environment more. About $80 \%$ of students are confused and do not understand themselves and their abilities in choosing further education, which is the initial part of career planning.

Based on research (Zen, 2012) decisions taken by individuals, are as aim and the essence of career guidance services, decision making is influenced by factors of knowledge, selfconcept, information about the environment and responsibility for the decisions taken. Decisions about the choice of work, position or career that someone aspires to have a close relationship with the education being pursued and must resolve. Based on the study (Zen, 2012), 40\% of students not knowing the potential of him.

Planning career many factors determine a student at the School of Secondary SMA (SMA) among others, the status of the social economy, the concept of self, understanding of information about careers and motivation to excel. In line with the opinion of the above (Dillard, 1985) proposed a five- to aim general of planning a career, namely: (1) get an understanding of self, (2) the satisfaction of personal, (3) prepare themselves to get placements and wages are adequate, (4) the effectiveness of use of time and (5) as efforts to achieve the success of personal and career that aspired - aspire.

Based on these definitions, it is clear that the purpose of guidance and counselling services that assist students to avoid effective daily life disrupted, including the issues 
relating to the acceptance and understanding of himself and make plans against his career. Through various types of services and support activities school counselors can do that, it can solve the phenomena described above. Based on a description of students' self- concepts in career planning. They can use the data that exist as references in preparing the program service counseling guidance in school, so that the service counseling guidance in school is more optimal, appropriate targets, and useful for students.

Based on the description of problems in the above, researchers are interested in researching the contribution of the concept of self to planning a career.The general aim of this study is to reveal the contribution of self- concept to career planning. While the specific objectives in this study are to describe: (1) describe the level of student self- concept, (2) describe the level of career planning, (3) describe the contribution of self- concept to career planning.

\section{Method}

This research is a descriptive correlational. The study population was all students of class XI and XII SMAN 1 V Timur Koto registered in the 2019/2020 Academic Year totaling 272 people and the study sample of 162 people. The sampling technique using technique stratified random sampling. The instrument used is the self-concept instrument and career planning instrument with a Likert model measurement scale. Results of test reliability using the formula of alpha Cronbach concept of self by 0.821 and planning career at 0,914 . Then the data analyzed using analysis descriptive and regression analysis simple by using the program Statistical Product and Service Solutions (SPSS) version 16.00.

\section{Results and Discussion}

\section{Contribution of Self Concept to Career Planning.}

Results of testing the hypothesis contributions concepts themselves to planning a career in SMAN $1 \mathrm{~V}$ Koto Timur as seen in the following table is:

Table 1. Research Hypothesis Testing Results

\begin{tabular}{cccc}
\hline Variable & $\mathbf{R}$ & R Square & Significance \\
$X-Y$ & 0.663 & 0,440 & 0,000 \\
\hline
\end{tabular}

Table 1 shows the results of testing the research hypothesis. In the self- concept and career planning variables, an R-value of 0.663 is obtained, which shows the regression coefficient of the self- concept of career planning. Rated R Square (R 2 ) of 0.0440 , meaning $44 \%$ contribution of the concept of self to the planning careers, $d$ ith level of significance 0,000 is smaller than 0.05 . The results of the analysis indicate self-concept contributes to career planning.

The results show that self-concept significantly contributes positively to career planning by $44 \%$. This finding was obtained based on a series of data analyses which showed that the test of the significance of self-concept with career planning. This means that the higher the student's self - concept, the higher the student's career planning. According to Winkel \& Hastuti (2004) factors that affect the planning of the career, one of them is the concept of self. The concept of self is a concept that is owned by someone about him. In line with the above 
opinion (Afdal et al., 2014) explains that in generating employment and education choices are based on self-understanding and the environment that has been understood, so that the goals that have been formulated are achieved.

It was explained that self-understanding is part of self-concept. This self-understanding can be seen from his perception of physical appearance, recognition of his abilities and deficiencies, the role he has and his life status, values, beliefs, and aspirations. In line with the above opinion, the results of Zein's research (2012) also states that one of the dominant factors that influence career planning is self-concept. This self-concept is the perception of appearance. The ability and role of status in life, values, beliefs, and aspirations. Basic selfconcepts tend to have realities that are not what they want. Circumstances have settled in himself even though places and situations are different.

Several studies were similar also resulted in a conclusion that is the same, that is Tennyson (Issaacson, 1992) reported the results of studies Vibian and Sherman in Palo Alto California that variable concept of self and motivation have contributed very significantly to the ability of students to plan careers. The concept of self is not fixed, but can be changed from time to time that is caused by the experience of the everyday. Therefore, in addition to school counselors who are always in contact with students, the role of subject teachers, parents and the environment is no less important in completing the concept of independent students (Zein, 2012). The role of the counselor of the school can impact positively on the students in making the planning of his career, it being understood counselor school can bridge the components of those, who in the end will be geared at birth planning careers that much better.

\section{Conclusion}

Based on the research that has been done in SMAN 1 Koto Timur with the title of the contribution of the concept of self to the planning of a career, then the results of the research can be concluded. There is a significant positive relationship between self-concept and career planning. This means that the better the self-concept, the better career planning. There is a significant contribution of the self-concept variable to the career planning variable. Students must improve their understanding of themselves as a whole and their environment. For this reason, school counselors need to provide guidance and counseling services about selfconcepts, so students can recognize themselves as a whole. So students do not experience confusion in planning a career. School counselors should carry out counseling services effectively and efficiently by making the results of this study a need assessment in developing a Counseling Guidance program. This is more focused on efforts to improve selfconcept. School counselors can provide information about self-concept services, in addition to school counselors can also provide group guidance services to students with a career planning theme, so students can make career plans that they will enter.

\section{References}

Afdal, A., Suya, M., Syamsu, S., \& Uman, U. (2014). Collaborative Career Guidance in Stabilizing the Career Planning of High School Students. Journal of Counseling and Education, 2 (3), 1. https://doi.org/10.29210/110000 
Annisa Apriliyanti, Mudjiran, MR (2016). Relationship between students 'self-concepts and students' social behavior. Indonesian Institute for Counseling, Education, and Therapy (IICET) , 2, 25-29.

Dillard, J.. (1985). Lifelong Career Planning. Chart of Merrill Publishing Company.

Fadli, RP, Alizamar, A., \& Afdal, A. (2017). Students' Perceptions about the Suitability of Career Direction Planning Based on Vocational High School Student Expertise Options. Counselor, 6, 1-9. https://doi.org/10.24036/02017627578-0-00

Issaacson, E. (1992). Career Information, Career Counseling \& Career Development.

Nengsih, N., Firman, F., \& Iswari, M. (2015). The Effect of Group Guidance Services on Planning the Career Direction of High School Students in Laboratory Development at Padang State University. Counselor, 4 (3), 1-11.

https://doi.org/10.24036/02015436466-0-00

Sharf, RS (1992). Applying Career Development Theory to Counseling. Cole Publishing Company.

Zen, M. (2012). (Study of Kota Pariaman High School Students) POSTGRADUATE PROGRAM DISSERTATION. Dominant Factors Influencing Career Planning (Study of Pariaman City High School Students), 276 (1), 1-276. 